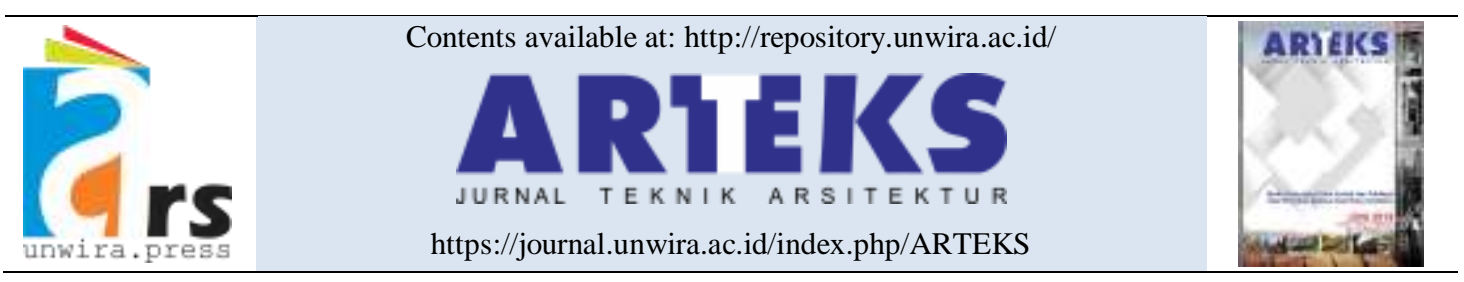

Research paper

doi: http://doi.org/10.30822/arteks.v3i1.55

\title{
Smart home design in Indonesia
}

\section{Yanita Mila Ardiani}

\author{
Department Engineering, Bina Nusantara University \\ Jl. Kyai H. Syahdan 9, Jakarta Barat, Indonesia
}

\begin{tabular}{|c|c|}
\hline ARTICLE INFO & ABSTRACT \\
\hline Article history: & \multirow{13}{*}{$\begin{array}{l}\text { The more the times, the more people want to get closer to the speed } \\
\text { of getting information. Achieving information today is facilitated by } \\
\text { the progress of technology. The case in living in a house, now has } \\
\text { been present tools that we can guide from our gadgets even though } \\
\text { the location is very far from where we live. Some of these tools can } \\
\text { be installed in the home, and there is a need for a standard and the } \\
\text { ways in which a home can be fully integrated with the tools. With } \\
\text { these smart home tools, we can control our home by distance. The } \\
\text { safety, the entertainment, the smart comfort living feeling, we can } \\
\text { achieve in the smart home design. The smart home is the home that } \\
\text { fulfill with smart tools to make our life easier with less cable and } \\
\text { fully supported by wifi and internet. In the smart home like this, our } \\
\text { life much simpler, and easier, and controlled well. This research } \\
\text { tries to collect the tools that can be put in the smart home and the } \\
\text { room and spaces in the home that supported. The Research method } \\
\text { is using qualitative methods, with experiments. The tools for Smart } \\
\text { home standardization are used in the experiments, so that we can } \\
\text { gain spaces that needed in the smart home design. So, the result of } \\
\text { this study is to find the smart home typhology that is using the tools } \\
\text { in the smart home standards. }\end{array}$} \\
\hline Received October 10, 2018 & \\
\hline Received in revised form Nov. 10, 2019 & \\
\hline Accepted November 22, 2018 & \\
\hline Available online December 01, 2018 & \\
\hline Keywords: & \\
\hline Smart & \\
\hline Home & \\
\hline Room & \\
\hline Corresponding author: Yanita Mila Ardiani & \\
\hline Department Engineering, Bina Nusantara & \\
\hline University, Indonesia & \\
\hline Email: millaardiani@binus.ac.id & \\
\hline
\end{tabular}

\section{Introduction}

In this current life, the more people want to get closer to the fastest information that they can get. Achieving today's information is made easy with the advancement of Technology. If in the old days we get information from the library, we come and look for books that match the information we seek and then borrow it. But today with technological advances we can access from home, then order them even books can be sent. Even this information we can not only from the library, but from newspapers, television and others. The development of this technology facilitates the achievement of information, especially with digital media, namely the internet. With the internet we can even find out information from the world's most remote with one button. Now, the world is changing with the invention in the field of the Internet, which comes from a tool called computers to a variety of mobile devices that have started mobile phones to I pad. The existence of the internet changes everything from lifestyles and patterns to human behavior. Now humans are faced with a modern life. People today want something with: instant, fast and simpler, to simplify their work and life needs. As an example of mothers who will be shopping in the market, she must see and find information on the internet first in the market where he can get the goods he wants, and the number, even he can order and send only via the internet. From children, mothers and parents. Now internet users are widespread because of the existence of social media on the internet that connect one person and others with domino effect (Acheaw and Larson 2010). All of that can be done by self service at home without us have to bother to the place to get the goods. 
Internet as a means of information of all things. With the nature of the internet that can answer the need for something fast, instant and simpler, then the internet is growing in many areas, as one of the styles of living. For example, many people have taken advantage of this internet technology media as a means of simplify the work, so that many jobs can be done and completed at home and then sent via mail. Many people do not need to go to the office, just send the results only, with this job become more effective and efficient and do not even go all the way to the office that spends a lot of energy in traveling. This system will save in urban transportation energy usage. The pattern of the function of space in the city will change much in accordance with the needs of the human lifestyle that also changed (Watson, Plattus, and Shibley 2003). Public spaces, and the shape of existing office space will change to accommodate the lifestyle of people living in the digital world of the Internet. Even the next few years, maybe we do not need a large office space or district, if all can be accessed from home. Our work is not only fixated on one office work, but many jobs. Thinking like this will also change the economic and cultural system. With the changing paradigm of thought and lifestyle adjust to the development of digital media internet, then we must design the appropriate city plan. The city must be designed in accordance with today's digital lifestyle. And this lifestyle already occurs in some of the society in Indonesia's big city like Jakarta and Surabaya, and will be increasing as the same as the the lifestyle that follow.

Things that affect the information system of an internet-based city, are:

a. The Speed of internet access;

b. Awareness of every human being in communicating in cyberspace;

c. From the City to the daily-daily at home too, people have begun to apply the principles of effective and effective in life;

d. All in the home all-round wireless, not only provide wireless signals to search for internet information only but also in operation in the house. All operations and controls in his house all with the internet and wirelessly;

e. When the owner is outside the home, the owner can control what is happening in his house with the media devices he has.

Even when the owner is inside the house. All remote controls of various electronics inside the house will not be used again when all have been connected with digital media, so the opretional should be only one button only. People want security in residence, not only that, he wants a (machine) perhaps if he can keep and control his house and it can be answered by internet. Thus, all are internet in answering all the questions that exist on this earth. The initial idea is simple, if someone is outside the house while he wants to control something that is at home easily from where he came from, is with the installation of cctv tools in his house then he can control from the media devices he, for example mobile phones connected to the internet without cable. And this has been discovered several years ago, following the discovery of this or the way a remote home controller has been found. As: (1) Suppose we turn on or fill the water reservoir so that until full, we can control from hundreds of kilometers we leave home, and the tandon will stop or stop by itself with us press a button from our media devices; (2) Turning on or opening, closing the window at our home time we have not arrived home, we can control by pressing one of the buttons in our media devices; (3) Turn on the power or the light by itself that we can do from a distance where we are just by pressing a button from our media devices (Paola 2009).

If such things can be done, we recognize them as smart homes, with systems inside and controllers that can control whatever is in the house even under the security of anyone who goes into the house and all is installed with a panel tool in each room. However, all of it is like a small machine like a robot in a house that regulates everything. The smart home is the with automatic machines that we can control from a distance with wireless internet media. And it will be completed with the research by defining problem: What the Home typhology in room and spaces for the smart home design using the smart home standard tools system? The purpose of the design is to find what standard tools for the smart home and to find the smart home design typhology that is needed in Indonesia?

\section{Methodology}

The method used for this research is a qualitative research method with experiment, where the author tries to collect data about what tools are now there to support smart home design (Groat and Wang 2004). Then the tools are paired in the rooms and the results will be given from this 
research is any room that is needed in a smart house and organization space in the house.

\section{Findings and discussion}

To gain the result first we are going to name and check the smart home standar tools and located in what rooms in the home, afterthat, we can gain one example of home typhology for smart home. This Smart home is highly favored by people who with high busyness, do not even trust a housekeeper or assistant to stay with their home. The advantages of this smart home are (Orpwood 2012):

a. Security. With this seamless home we become safe from people who want fun, doing criminal acts on our homes. we put cctv in many places and control it through the media devices that we have. Supervision is done at home with no dwelling cctv camera to control things that happen in the house. Eg: Stoves connected with detection if we forgot to turn it off, we can command the alarm to the mobile device from the occupants;

b. Operational. Operation in the automatic sense, windows at 6 am and $6 \mathrm{pm}$ will open and close itself, when we at home with the sound sensor, fingers and eyes can all automatically open themselves. Daily operations if we do regular work. For example: turn on the water tank and turn off by itself by the media devices we have;

c. Work. Jobs can be controlled via smart board and what are the things we do, from our media devices we have our own alarm or reminder even where we do the job;

d. Entertainment. As a means of entertainment, smart home gives us the flexibility, relax time to enjoy the dishes or even mingle with friends with a given area is a kind of wall connected with the big screen as connected with computers or large media devices;

e. Controller. Controller means home to be automatic at certain hours to do its activities, for example at 7 am, laundry machine works alone. The most thing is to control everything that happens our house, for example if we forget to turn off the stove, we can check through the media devices that we have and turn them off it from the place where we are.
In the smart home, the system required:

a. Wireless, so it takes high internet connectivity and supporting infrastructure;

b. Server space: Space where the "brain" works. Where there is a computer that works 24 hours operates all commands from tools;

c. Control panel: Control panel that can be placed on the front of each room;

d. Transmitter Area: This transmitter area is placed in concrete on the highest floor of the house to transmit and receive commands from the technological tools used;

e. Height distortion: The height difference in the ceiling between the first and second floors in order not to connect between the power cable and the internet data cable used;

f. Electric Shaft: Shaft where the electrical cable will be placed from the rooms on the floor above it;

g. Shaft Internet data: Shaft where will be placed internet data cable from spaces on the floor above it;

h. Automatic Utility: The repair room of this utility is required for the controller in case of errors or overrides;

i. Smart board: This smart board is usually provided in the bedroom or living room. In the form of a large board that is driven by the hand sensor to control the tools and give orders for the tools it works. This board is also able to open the internet, the page we want eg, facebook, or check email. Here are the necessary rooms and arrangements in a smart house:

\section{A. Family room}

In this family room there is a means of entertainment for the family with tools that can be guided directly by mobile or ipad without remote respectively (tv, radio, cctv, etc.) All of this is controlled in control panel placed on the front of the family room. 

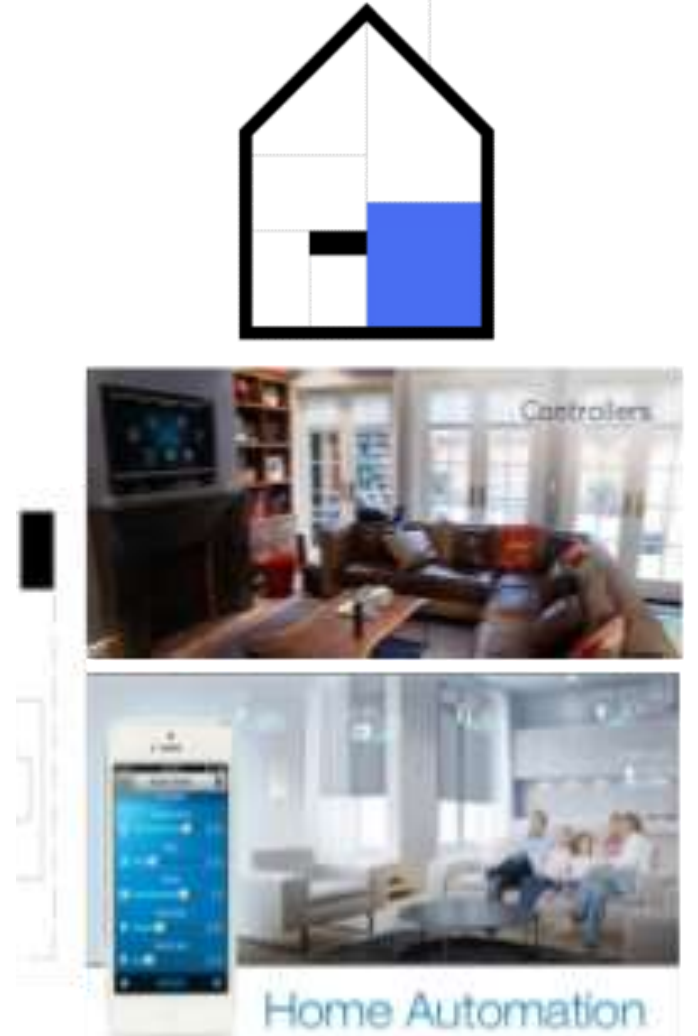

Figure 1. Digitalisation of Yunita Mila Ardiani and from web: https://www.control4.com

\section{B. Dining room}

The dining room is equipped with sensors in the pantry, with electric stoves and electric cooking utensils that can be controlled through electric tools connected to the handset or the owner's pad.
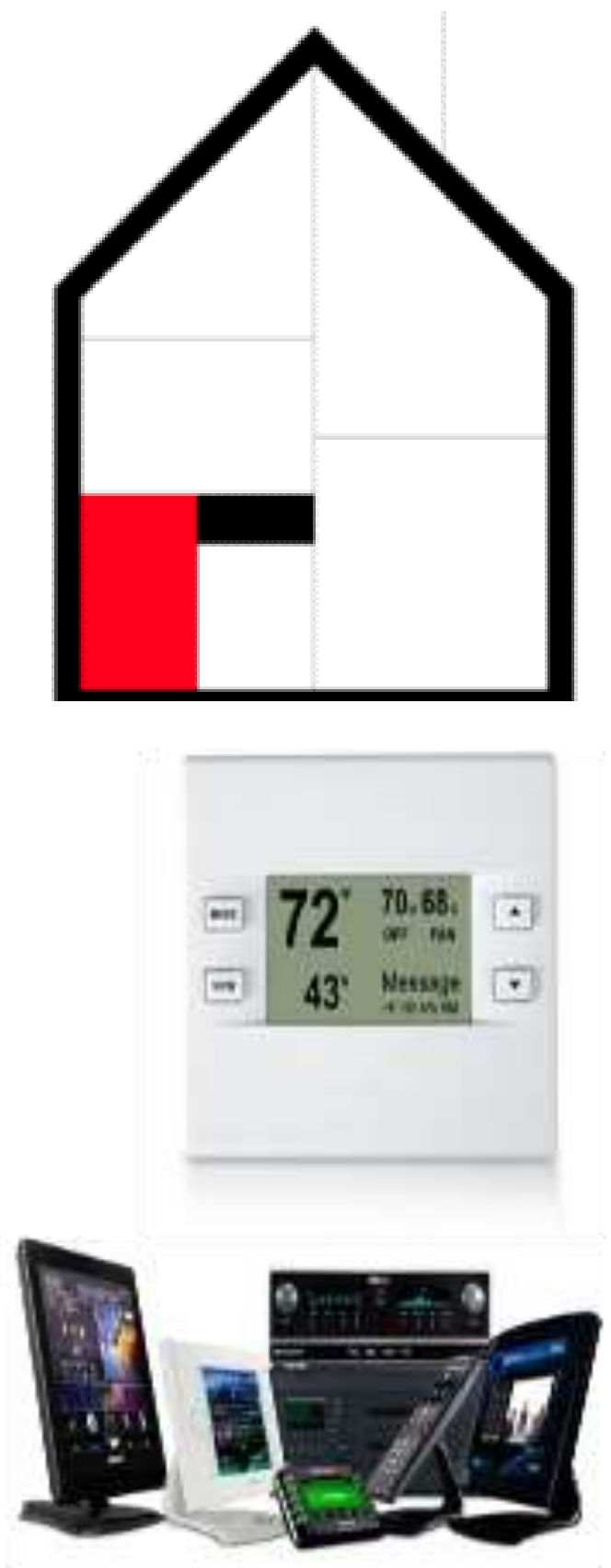

Figure 2. Digitalisation of Yunita Mila Ardiani and from web: https://www.control4.com

\section{Bedrooms}

The bedrooms are equipped with sensory room temperature gadget that we can turn on or off on our mobile phone even if we are away from home. Lights and other sensory devices that can be connected to windows or doors. Room lights are the same as being connected with a switch that connects directly to our electronic media. 

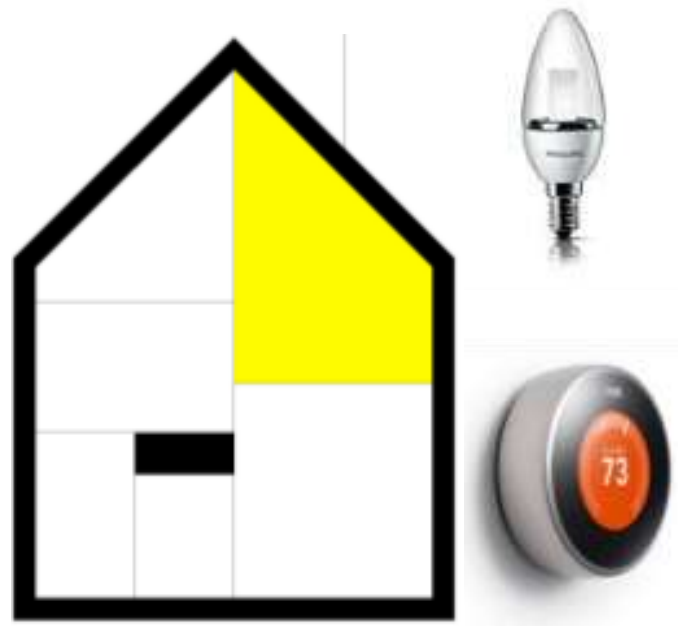

Figure 3. Digitalisation of Yunita Mila Ardiani and from web: https://www.control4.com

\section{Child's bedroom}

Child's room the same, especially if you have a baby can be given a sensory device that lights up if the baby cries, and all of this is monitored in the panel space that on the front of each bedroom.
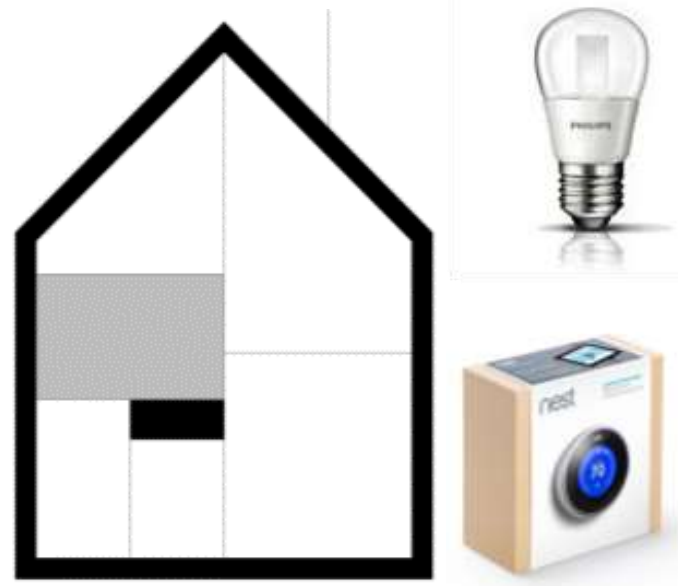

Figure 4. Digitalisation of Yunita Mila Ardiani and from web: https://www.control4.com

\section{E. Bathroom}

The bathroom is equipped with lights that connect directly to the switch that we can turn off via electronic media even through we are not the house.

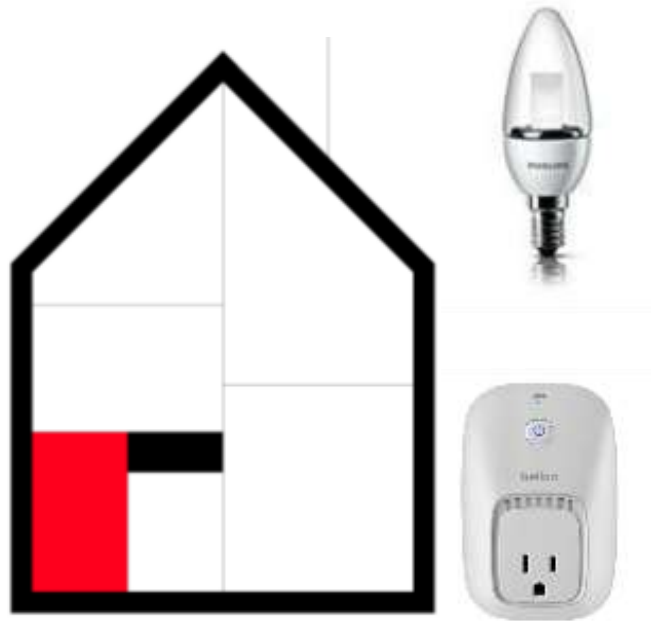

Figure 5. Digitalisation of Yunita Mila Ardiani and from web: https://www.belkin.com

\section{F. Service room}

Service room where inside is ironing room and laundr room using machine, also warehouse and other equipment. We can turn off the iron that we ma forget to turn off, with a switch that is connected directly to our electronic media, to be integrated well then it can be controlled through the control panel in the front area of this service room.

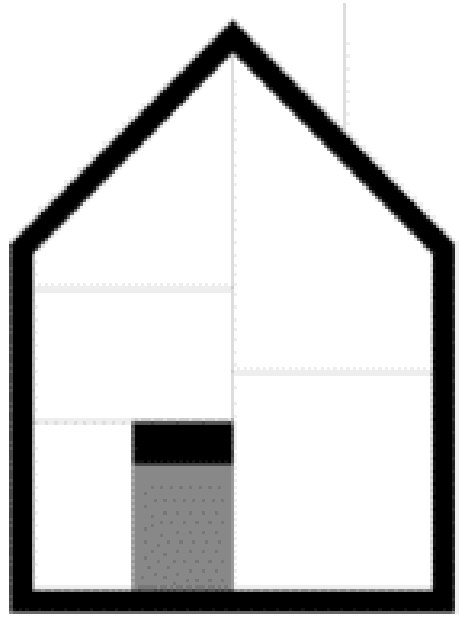




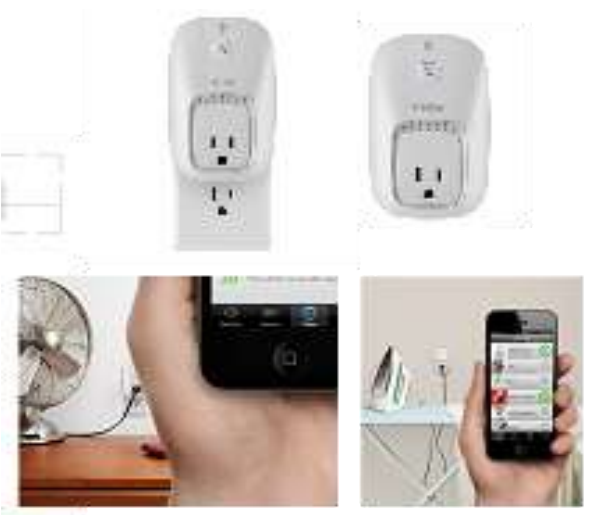

Figure 6. Digitalisation of Yunita Mila Ardiani and from web: https://www.belkin.com

\section{G. Garage and warehouse}

Not much different from the service room, we can use the switch which connect the lights and connect to the electronic media that we can control. Another tool is an electronic garage that the sensor can open and close on its own.

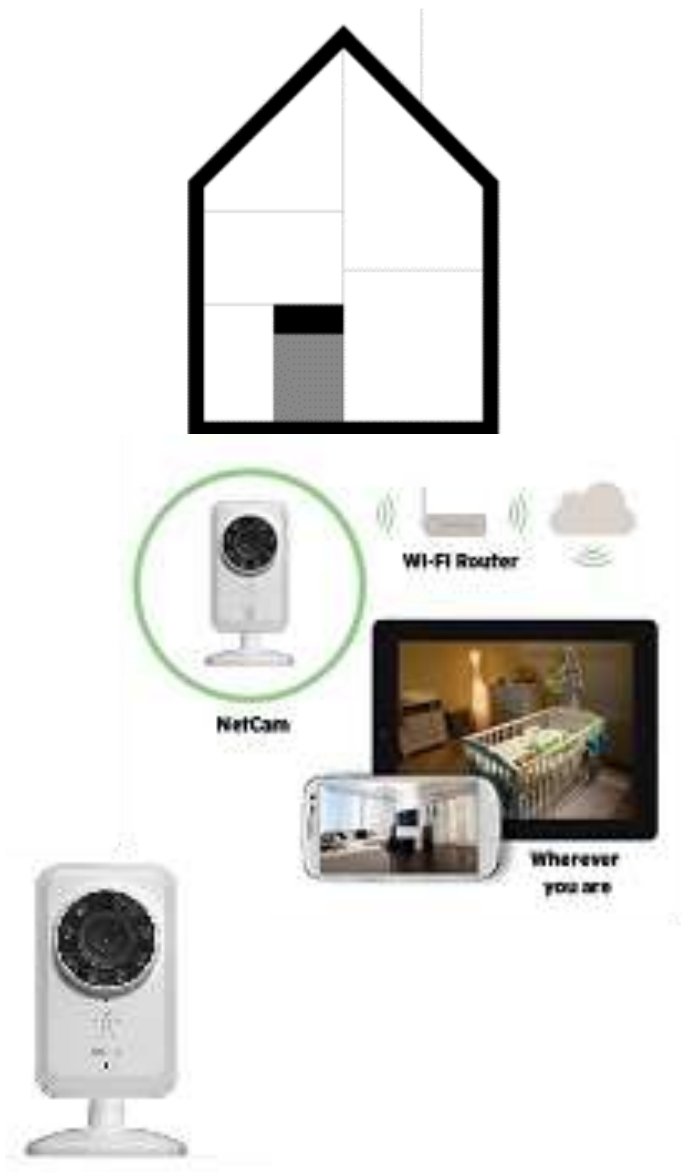

Figure 7. Digitalisation of Yunita Mila Ardiani and from web: https://www.belkin.com

\section{H. Garden}

Like most homes, cctv plays animportant role, and it is common to monitor our homes with the help of cctv. And this is connected directly through control panel first that can be put together in the garage area.
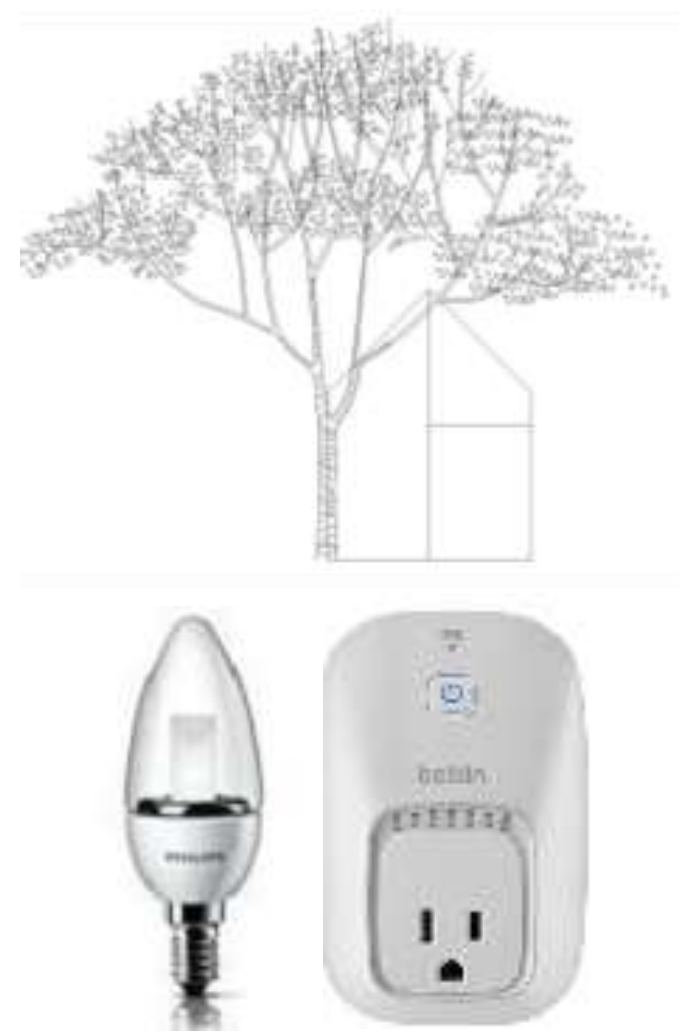

Figure 8. Digitalisation of Yunita Mila Ardiani and from web: https://www.belkin.com

\section{Conclusion}

The smart home using all standard smart home tools in each room. Rooms with panels that can be controlled in server room, sent to the transmitter area. All that using the tools that have been available in the market. 


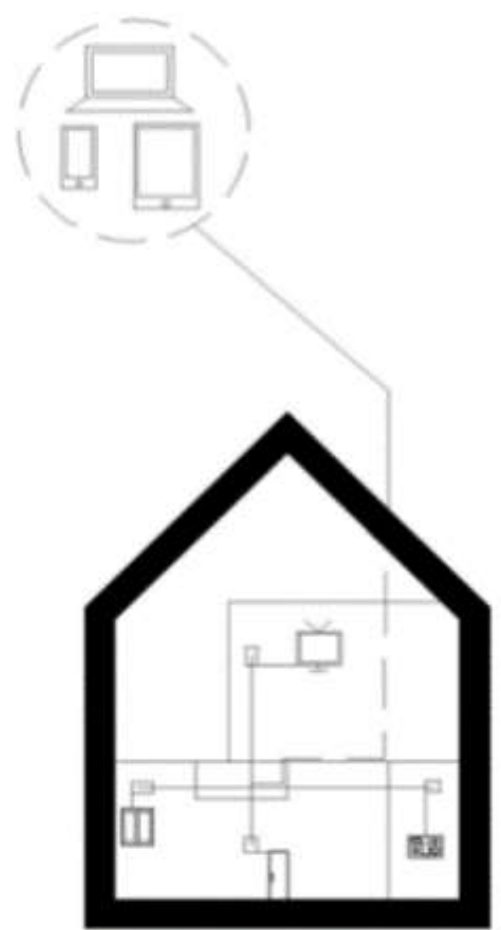

Figure 9. Yunita Mila Ardiani’s drawing

The example is smart home design that are developed by Bina Nusantara Student: Prabaswara. This smart home design tries to have more open spaces that all wifi can be again to all rooms and can be achieved in all tha control panel of each rooms. Tha design is modern, and have the server room in the first floor that connected to the transmitted floor up stair that spread the information to our media devices.
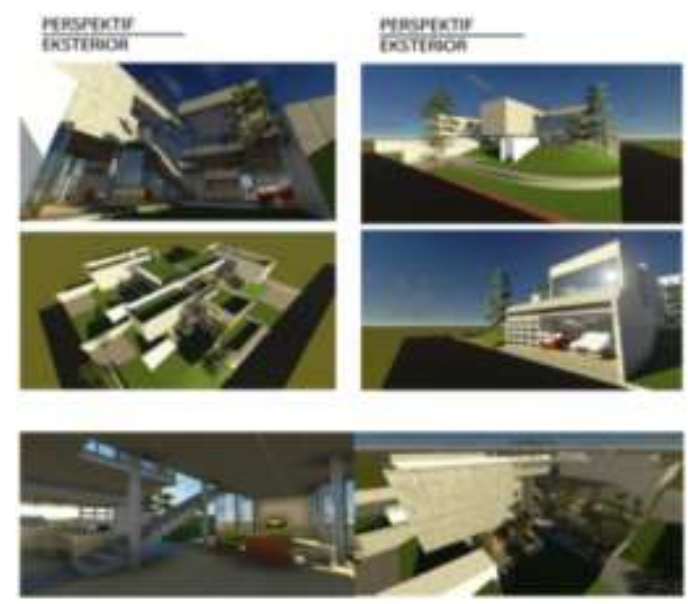

Figure 10. The smart house by Prabaswara (selected works that contest the design of smart house using Smart Home's theory by Yanita Mila Ardiani)

\section{References}

Acheaw, M. Owusu, and Agatha Gifty Larson. 2010. "Use of Social Media and Its Impact on Academic Performance of Tertiary Institution Students: A Study of Koforidua Polytechnic, Ghana." The Prevention Research, .

Groat, Linda, and David Wang. 2004. "Architectural Research Methods." Nexus Network Journal. https://doi.org/10.1007/s00004-004-0006-7.

Orpwood, Roger. 2012. "Smart Homes." In Pathy's Principles and Practice of Geriatric Medicine: Fifth Edition. https://doi.org/10.1002/9781119952930.ch1 24.

Paola, Sassi. 2009. No Title. New York: Routledge.

Watson, Donald, Alan Plattus, and Robert Shibley. 2003. Standards for Urban Design. New York: McGraw-Hill. 
ARTEKS : Jurnal Teknik Arsitektur, Volume. 3, Nomor 1, Desember 2018 eISSN 2541-1217; pSSN 2541-0598 